Małgorzata Martens-Czarnecka (Warszawa)

\title{
The Christian Nubia and the Arabs
}

Tubia constituted the area in the Nile Valley in the present day Sudan (Fig. 1), 1 the area which spread from the first cataract up to the place in the neighbourhood of Soba, where the White Nile meets the Blue Nile. In Antiquity, the area was inhabited by the population using a common language - Old Nubian ${ }^{1}$.

In mid $6^{\text {th }}$ century three kingdoms occupied the above described area: Nobatia in the north with the capital in Faras, Macuria south of the second cataract with the capital in Old Dongola and further south, at the sixth cataract - Alodia with the capital in Soba, the city located near the present day Khartoum².

It is well known that the Christian faith penetrated the Nubian territory very early ${ }^{3}$. Egypt, bordering Nubia on the north become entirely Christian as early as the beginning of the $4^{\text {th }}$ century. Starting from the end of the $4^{\text {th }}$ century and at the beginning of the $6^{\text {th }}$ century, Christian bishops resided on the island of Phile and Syene (Aswan) ${ }^{4}$, hermits probably settled in $\mathrm{Nubia}^{5}$ and we also have archeologically confirmed presence of Christian graves in that territory ${ }^{6}$. However official acceptance of Christianity as a state religion took place in the second half of the $6^{\text {th }}$ century (in the years 540-580) thanks to missions send by the Byzantine Court ${ }^{7}$. Acceptance of Christianity in Nubia had very interesting and even adventurous character ${ }^{8}$. The process was of major importance for the entire structure of the state, as it preceeds the merger of Nubian kingdoms into one state'

\footnotetext{
${ }^{1}$ D.A. Welsby, The medieval Kingdoms of Nubia, Pagans, Christians and Muslims along the Middle Nile, London 2002, p. 7-8.

${ }^{2}$ Ibidem, p. $24-30$.

${ }^{3}$ Ibidem, p. 31-32, 35; S. JаковіеLsкi, Faras III. A History of the Bishopric of Pachoras on the Basis of Coptic Inscriptions, Warszawa 1972, p. 17-24.

${ }^{4}$ U. Monneret de Villard, Storia della Nubia christiana, Roma 1936, p. $44-45$ ( $4^{\text {th }} / 5^{\text {th }}$ century).

${ }^{5}$ However, see ibidem, p. 63-64.

${ }^{6}$ W.Y. Adams, H-Ä. Nordström, The Archeological Survey on the West Bank of the Nile, Ku 11, 1963, p. 30-31; T. Säve-Söderbergh, Preliminary Report of the Scandinavian Joint Expedition, Ku 11, 1963, p. 66-67; L. Kirwan, Studies on the History of Late Antique and Christian Nubia, eds. T. HäGg, L. TöRőK, D.A. Welsby, Suffolk 2002, XV - p. 202; XXI - p. 123.

${ }^{7}$ Cf. L. Kirwan, op. cit., XX - p. 127-130.

${ }^{8}$ Cf. G. VAntini, Christianity in the Sudan, Bologna 1981, p. 33-50.

${ }^{9}$ S. JАковIELSKI, op. cit., p. 35-36.
} 
Nubia immediately found itself in the area of influence of Byzantine culture. That led to certain cultural unification with all the countries where Christianity was present. Within the frame of that unification in Nubia, as elsewhere, components of Byzantine administration system were introduced ${ }^{10}$. Nubian church copied the patterns of ceremonials and liturgy of the Eastern Church and first of all the Greek language, the linqua franca of the area of Byzantine culture, gained popularity. Greek designations of state functionaries of the kingdom were adopted. The king - basileus - held the position of the head of the court which apparently was modelled on the Byzantine one. The king nominated bishops, subsequently approved by the patriarch of Alexandria. The king's governor held the title of eparchos - whose residence was in the North of Nubia in Qasr Ibrim. The domesticos was a commander of the royal guard while meizoteros was in charge of economic matters. Those posts and many others according to Byzantine pattern were introduced in Nubia during the reign of Emperor Justinian I. All that resulted in creation of well organized, politically and militarily strong state.

So, in the middle of the $7^{\text {th }}$ century the Nubian Kingdom, organized according to Byzantine pattern, united by one official language, state structure and royal rule as well as one religion, faced in 641 the fact of Arab conquest of Egypt. Soon afterwards in 642 the Arab army crossed the line of the first cataract and entered the territory belonging to Nubians ${ }^{11}$. The peace treaty, signed by Nubians and Arabs was not adhered to by either party, which over nearly ten years resulted in numerous clashes.

Many Arab writers give account of those clashes describing cavalry combats as well as brave and brutal Nubian archers who earned the Arab name of rumat al-hadaq - pupil-smiters. Women and children were killed or kidnaped, prisoners were taken, towns and villages destroyed. That lead to great Arab campaign in 652, which after siege of Makurian capital, Old Dongola, ended with officially signed peace treaty, the so-called Baqt ${ }^{12}$. In practice the agreement made political-commercial agreement confirming the centuries-old tradition of relations between Nubia and Egypt. Our knowledge on the entire substance of that treaty has been gained from works of the Arab historian Maqrizi, who was active in the $15^{\text {th }}$ century but had access to much earlier sources ${ }^{13}$.

On the ground of that treaty both Arabs and Nubians could freely travel in the territory of both countries but settlement was forbidden. Nubians were obliged to return slaves who kept escaping from Egypt, had to take care of the mosque built

\footnotetext{
${ }^{10}$ Ibidem, p. 15; T. HäGG, Some remarks on the use of Greek in Nubia, [in:] Nubian Studies. Proceedings of the Symposium for Nubian Studies, Cambridge 1978, ed. J.M. Plumley, Warminster 1982, p. 104-105; L. TőRőK, Money, Economy and Administration in Christian Nubia, [in:] Études Nubiennes, Colloque de Chantilly 1975, Le Caire 1978, p. 302-309.

${ }^{11}$ U. Monneret de Villard, op. cit., p. 71-78; K. Micha£owski, La Nubie chrétienne, AfB 3, 1965, p. 15.

${ }^{12}$ Cf. D.A. WelsBY, op. cit., p. 69-71.

${ }^{13}$ G. Vantini, Oriental Sources Concerning Nubia, Heidelberg-Warsaw 1975, p. 638-644.
} 
at the outskirts of Dongola, each year supply Egypt with certain number of slaves and Arabs in return were to supply the kingdom with food, textiles, wine and horses. Despite the earlier doubts as for the existence of such a treaty, a few documents written in Arabic and kept in Qasr Ibrim archive, discoveried by the English mission enabled different approach. Arab letters to the king and Nubian functionaries complaining that Nubians breach the principles of the treaty, fully confirm the rightness of written sources ${ }^{14}$. Over entire period of Nubian-Arab contacts, Baqt was breached by military expeditions as well as in the field of political and commercial principles. In 748 the king Cyriacus (Kyriakos) with the Nubian army conquered the Upper Egypt, reaching as far north as close to Cairo. The reason for that venture was imprisonment of Michael, the Patriarch of Alexandria by the Umayyad Egyptian governor ${ }^{15}$. As the result of prolonged negotiations the Patriarch was released. It can be seen that in that period Nubia was capable of political and military ventures, which testifies the power of the kingdom.

Another example of similar policy was the travel of the young heir to the throne in 835 - George (Georgios), son of Zacharias, to Baghdad to see the caliph alMu'tasim $^{16}$. Both Arab and Christian sources describe that visit as an important political success. The regulations contained in the Baqt were renegotiated, which normalized relations between Caliphate and Christian Nubia and ended wars between those parties for certain period. George traveled on the camel back, under red umbrella, wearing the crown topped with the cross and distributed gifts made of gold or silver ${ }^{17}$. Undoubtedly his travel was connected with difficult internal situation in Egypt at the time of Fatimid dynasty rule.

The first half of the $10^{\text {th }}$ century was the period of peace and development for the kingdom of Nubia. At the same time the first bigger groups of the Arab settlers began to appear on the territory south to the first cataract. That fact is indicated by numerous Arab cementaries at Taffa, Kalabsha, Qurta and Derr. The Arab historian of that time, Al-Mas'udi left descriptions of rich Nubian towns including also Dongola. Long Nubian occupation of southern Egypt ${ }^{18}$ yielded reconstruction in Nubian style of the famous St. Symeon monastery in Assuan. Certain manuscripts from the monastery give account of three-years Nubian occupation of Arab towns of Esna, Armat and Abnout. The Nubian king Salomon, who abdicated and became a monk in the St. Onuphrius monastery, was invited by vizier Badr to Cairo, where he was highly honoured and presented with the rich house. In turn one of his successors, king George (Georgios) IV also resigned the throne, but went to the Egyptian monastery in Wadi Natrun, where he died in $1158^{19}$.

\footnotetext{
${ }^{14}$ J.M. Plumley, Qasr Ibrim and Islam, ET.SP 12, 1983, p. 159.

${ }^{15}$ K. Micha£owsKi, op. cit., p. 16-17.

${ }^{16}$ G. VANTini, op. cit., p. 644-647.

${ }^{17}$ Ibidem, p. 421.

${ }^{18}$ K. Micha£owski, op. cit., p. 19-20.

${ }^{19}$ Ibidem, p. 21.
} 
Peace and prosperity ended together with the fall of Fatimide dynasty in 1171. The Nubian king organized the expedition to Egypt in order to help Fatimides. That of course caused the retaliation from, this time, Ayyubide dynasty. Their Egyptian ruler Saladin gathered the army under command of his brother Turan-Shah and sent it to Nubia. The town of Qasr Ibrim was conquered, its population slithered, the bishop subjected to tortures and the cathedral converted into a mosque. Probably also the Faras cathedral was destroyed the same year ${ }^{20}$.

The $13^{\text {th }}$ century marks slow decline of the kingdom of Nubia ${ }^{21}$. Hostile Black tribes from the South and South-West appear in the Mid Valley of Nile. Fights weakened the kingdom; slow islamization of the country followed, royal rule and Christian faith fell and subsequently culture and arts deteriorated. The royal palace in Dongola was converted into a mosque in 1317 (Fig. 2).

The history of military as well as political or commercial Nubian-Arabic contacts over entire period of existence of the Christian Kingdom of Nubia undoubtedly had to bring about certain artistic trends in Nubia originating from rich heritage of Muslim culture. As long as the kingdom was strong, united with one language and religion and also uniform culture based on Byzantine patterns, symptoms of islamization were not visible, which is confirmed in the material discovered by archeologists. An art that developed in Nubia in that period $\left(9^{\text {th }}-11^{\text {th }}\right.$ century), based on the Byzantine patterns created specific phenomenon, similar to the case of Ethiopia, recognizable at the first glance. It concerned all fields of art and craftsmanship. Both in architecture and wall painting that specific ByzantineNubian mixture can be traced, which not only differentiated that art from the others but also shown the consistent trends in particular periods over the entire territory of the Nubian Kingdom ${ }^{22}$.

Changes that were taking place in the Nubian art can be traced in Nubian wall painting from Faras and Dongola. The classic period of that art falls in the end of the $10^{\text {th }}$ and entire $11^{\text {th }}$ century ${ }^{23}$ (Figs $\left.3,4,5\right)$. However, in course of time and particularly from the $12^{\text {th }}$ century ${ }^{24}$, together with gradual weakening of the Nubian state, new components of art can be noticed. The art gradually becomes less homogenous, which is distinctly manifested in painting (Figs 6, 7). Greater freedom in selection of subjects, form and colouring, smaller size and different

\footnotetext{
${ }^{20}$ Ibidem, p. 24.

${ }^{21}$ Cf. ibidem. p. 25; D.A. WelsBy, op. cit., p. 242-243.

${ }^{22}$ E.g. D.A. Welsby, op. cit., p. 216-241.

${ }^{23}$ M. Martens-Czarnecka, Faras VII. Les éléments décoratifs sur les peintures de la Cathédrale de Faras, Varsovie 1982, p. 50-88; EADEM, Byzantine Models in Nubian Iconography, GAMAR 6, 2010, p. 109-118; EAdEM, The Wall Paintings from The Monastery on Kom H in Dongola, Warsaw 2011, p. 239-252, 261-263.

${ }^{24}$ M. Martens-Czarnecka, The Wall Paintings..., p. 252-260, 263-264.
} 
composition of the representations begin to appear more and more often. New artistic influences seem to appear. In many cases those influences can be described just as 'Arabic'. They can be found in elements of vestments, composition and the very character. It seems that the era of Byzantine influences is ending. It was most likely caused by intensified contacts with Arabs, growing Arab migration into the Nubian territory and at the same time weakening and poverty of the Nubian church, lesser position of monasteries and decreasing role of the royal support.

As far as the wall painting is concerned I will limit myself to two examples, that perfectly illustrate the above remarks on Arabic elements in the late Nubian art. Both examples originate from so called Southwestern Annex of the monastery on kom $\mathrm{H}$ in Old Dongola (Fig. 8).

Putting aside an interpretation of the subjects of representations, the first composition $^{25}$ consists of a sequence of episodes, of which the central scene makes a financial transaction, whose completion is to be celebrated by a feast on lamb. Two men are sited on the wide bed in the interior (Fig. 9) behind a folded curtain. Between the two men dark skinned servant or slave waits for orders. Below that composition, slightly to the right, another servant skins the lamb, more lambs waits behind a round fence (Fig. 10). Above the main episode (Fig. 11) one more man sits on semi-round sofa hand outstretched as if in gesture of greeting towards approaching couple, man and woman clad in white robes.

The form of the painting seems to constitute a fragment from illuminated Arab manuscripts. The interior with folded decorated curtain hanged on a wooden pol; Arabic type angarebs - beds used also for sitting ${ }^{26}$; attires of men - small caps, caftans, wide coloured galigaskins and pointed shoes as well as the attire of the couple - man in galabiyah and top covering the woman's head - all those confirm definite Arabic influences visible on the painting in question also manifested in even so minor details as decoration of robes in the form of stripes on sleeves with an imitation of Kufic inscriptions, so called tirazes ${ }^{27}$. Other basic Arabic customs such as position of men sited with crossed legs or celebrating the meeting with the feast on lamb are also manifested in the painting. The representation of lambs crowded behind the round fence reminds scenes from Arab village, where lambs and goats are closed in round zeribas built of thorn branches.

The second of the paintings in question is bordered by the frame of icon ${ }^{28}$. The composition consists of three horizontal rows of male figures (Fig. 12). The men constitute two types of figures in different attires. Some have animal masks on their faces, the others are clad in sleeveless chitons and long galigaskins, skirts, shawls

\footnotetext{
${ }^{25}$ Ibidem, p. 121-125.

${ }^{26}$ G. Erster, Nubien, Goldland am Nil, Zürich-Stuttgart 1964, p. 202.

${ }^{27}$ S. BLAIR, Islamic Inscriptions, Edinburgh 1998, p. 164-173; J. BLoom, S. BlAIR, Islamic Arts, London 1997, p. 225-226, fig. 103, 117.

${ }^{28}$ M. Martens-Czarnecka, The Wall Paintings..., p. 233-238.
} 
and turbans with bands. Both groups are represented dancing. The figures are supplemented with inscriptions in so far incomprehensible Nubian language. Two folkloristic streams can be clearly seen in an iconography of that scene - one from black Africa and the other from Africa dominated by Arabic culture. Analogies concerning shape of masks, attires and musical instruments as well as undoubtedly ritual character of the dance itself can be found in the culture of peoples inhabiting Central Africa (present territories of the Western Sudan, Chad and Niger). In turn their attires - tunics, skirts, galigaskins and turbans with bands are the components of attires of Arab tribes known not only from the local folklore but also from numerous illuminated manuscripts ${ }^{29}$, among others Syrian or Coptic-Arab ${ }^{30}$. In the scene of dance, for the first time in archaeological material, the attires of men and their folk dance give evidence that the Nubian society was multicultural. The Arabic component was becoming predominant and also African folklore appeared in the art that used to belong, at least partially, to the Mediterranean world.

Arab influence can also be seen in that late-period church architecture ${ }^{31}$. In the latest stage of development of Nubian church architecture, the form of buildings was affected by the idea of the multi-axial and multi-bayed hall system, a basic compositional motif of the Islamic cult edifices. The Arabic halls of prayer, socalled harams divided by columns into several bays having a square plan and their homogeneous form, could influenced the plans of Nubian churches (Fig. 13). They are superimposed on the division of the naos into nine fields leading to the annihilation of differences between the nave and the aisles and to the obliteration of the individual character of the central bay. This solution coexisted with the traditional arrangement of eastern and western part of the structure of the Nubian churches. We can quote as examples the church of Rafael in Tamit, the church in Mediq near Gerf Hessein and the church in Kaw.

The good examples of the Muslim influence on Nubian art are the decoration of the arch of the doorway, giving access to commemorative part with grave recesses in North-Western Complex on kom H in Dongola (Fig. 14) and of the design of ceramic plate (Fig. 15) that must have decorated interior of the same monastery in Dongola.

This type of arches ${ }^{32}$ imitates so-called l'arc polylobé known in Islamic architecture of $11^{\text {th }}$ and $12^{\text {th }}$ centuries. The internal part of the arch is decorated

\footnotetext{
${ }^{29}$ Islam. Art and Architecture, ed. M. Hattstein, P. Delius, Cologne 2000, p. 107.

${ }^{30} \mathrm{~J}$. Leroy, Les manuscrits syriaques à peitures conservés dans les bibliothéques d'Europe et d'Orient, Paris 1964, p. 133, 134-135, 241-252, ill. 62-64; IDEM, Les manuscrits coptes et coptes-arabes illustrés, Paris 1974, p. 113-148, ill. 41-74; p. 110-113, ill. 39-40, 101-104, 148-153.

${ }^{31}$ P.M. Gartkiewicz, New Outline of the History of Nubian Church Architecture, BAB 55, 1980, p. 142 , ill. 19.

${ }^{32}$ I. RYL-Preibisz, Architectural Decorative Elements Recently Discovered at Dongola, [in:] Actes de la VIII Conférence International des Études Nubienne, Lille 11 - 17 septembre 1994, vol. II, Découvertes archéologiques, Lille 1997, p. 230-231.
} 
with six rounded recesses and leans against the modeled columns and capitals. All is made out of thick coats of plaster a kind of local stucco which is supported with small columns toped with the capitals which shape are cubic in the upper part divided from the lower one by the sharp narrowing. Such design of capitals evidently links them with the Muslim ones.

The open-work ceramic plate $\left(12 / 13^{\text {th }} \text { century }\right)^{33}$ is unfortunately only fragmentarily preserved. Nevertheless it can be clearly noticed that a half-sited male figure in Arabic attire makes the main component of the decoration. That figure wears turban, is clad in caftan and wide galigaskins and leans on the sword with richly decorated sheath. The same decoration molded on one side was only painted on the other, so it was visible on both sides, which indicates that the openwork plate served as a kind of grating or partition.

The abode analysis clearly shows that the culture of Christian Nubia, originally based to considerable extent on Byzantine art, in course of time subjected to more and more intense Arabic influence, significantly changed. Arabic components became predominant, which over following centuries led to creation of Arabic culture of the contemporary Sudan (Fig. 16, 17, 18, 19).

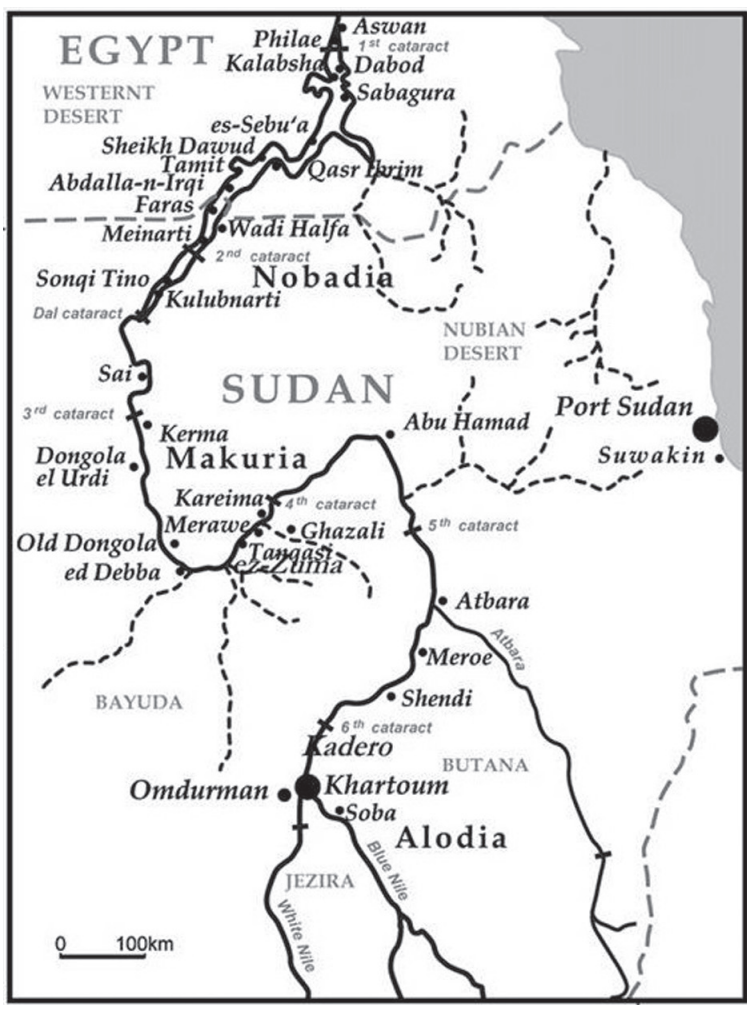

Fig. 1. Sketch Map of the Nubian kingdoms in the Middle Nile Valley

${ }^{33}$ I. RYL-PreIBISZ, op. cit., p. 230. 


\section{Bibliography}

\section{Secondary literature}

Adams W.Y., Nordström H-Ä., The Archeological Survey on the West Bank of the Nile, Ku 11, 1963, p. 10-46. BlaIr S., Islamic Inscriptions, Edinburgh 1998.

Bloom J., Blair S., Islamic Arts, London 1997.

Erster G., Nubien, Goldland am Nil, Zürich-Stuttgart 1964.

GartKiewicz P.M., New Outline of the History of Nubian Church Architecture, BAB 55, 1980, p. 137-144.

HäGG T., Some remarks on the use of Greek in Nubia, [in:] Nubian Studies. Proceedings of the Symposium for Nubian Studies, Cambridge 1978, ed. J.M. Plumley, Warminster 1982, p. 103-107.

Islam. Art and Architecture, ed. M. Hattstein, P. Delius, Cologne 2000.

JаковіеLsкi S., Faras III. A History of the Bishopric of Pachoras on the Basis of Coptic Inscriptions, Warszawa 1972.

Kirwan L., Studies on the History of Late Antique and Christian Nubia, eds. T. HäGg, L. Tőröк, D.A. WelsBy, Suffolk 2002.

LEROY J., Les manuscrits syriaques à peitures conservés dans les bibliothéques d'Europe et d'Orient, Paris 1964.

LEROY J., Les manuscrits coptes et coptes-arabes illustrés, Paris 1974.

Martens-Czarnecka M., Byzantine Models in Nubian Iconography, GAMAR 6, 2010, p. 109-118.

Martens-Czarnecka M., Faras VII. Les éléments décoratifs sur les peintures de la Cathédrale de Faras, Varsovie 1982.

Martens-Czarnecka M., The Wall Paintings from The Monastery on Kom H in Dongola, Warsaw 2011.

Micha£owski K., La Nubie chrétienne, AfB 3, 1965, p. 9-26.

Monneret de Villard U., Storia della Nubia christiana, Roma 1936.

Plumley J.M., Qasr Ibrim and Islam, ET.SP 12, 1983, p. 157-170.

Ryl-Preibisz I., Architectural Decorative Elements Recently Discovered at Dongola, [in:] Actes de la VIII Conférence International des Études Nubienne, Lille 11 - 17 septembre 1994, vol. II, Découvertes archéologiques, Lille 1997, p. 227-234.

Säve-Söderbergh T., Preliminary Report of the Scandinavian Joint Expedition, Ku 11, 1963, p. 66-67.

TöRöK L., Money, Economy and Administration in Christian Nubia, [in:] Études Nubiennes, Colloque de Chantilly 1975, Le Caire 1978, p. 302-309.

Vantini G., Christianity in the Sudan, Bologna 1981.

Vantini G., Oriental Sources Concerning Nubia, Heidelberg-Warsaw 1975.

Welsby D.A., The medieval Kingdoms of Nubia, Pagans, Christians and Muslims along the Middle Nile, London 2002.

Abstract. Nubia constituted the area in the Nile Valley in the present day Sudan, the area which spread from the first cataract up to the place where the White Nile meets the Blue Nile. The area was inhabited by the population using a common language - Old Nubian. In the second half of the sixth century thanks to the missions send by the Byzantine Court, Nubia accepted Christianity as a state 
religion. Nubia immediately found itself in the area of influence of Byzantine culture. Byzantine administration, liturgy of the Eastern Church and the Greek language were introduced.

In 641 the Arab conquest of Egypt took place. Soon after that in 642, the Arab army entered the Nubian territory and from this date centuries of clashes and peace treaties characterized relations between Nubians and Arab peoples. The $13^{\text {th }}$ century marks slow decline of the kingdom of Nubia. Hostile Negro tribes from the South and South-West appear in the Mid Valley of Nile. Fights weaken the kingdom; slow islamization of the country follows, royal rule and Christian faith falls and together with those culture and arts deteriorates.

The history of military as well as political or commercial Nubian-Arabic contacts over entire period of existence of Christian kingdom of Nubia undoubtedly had to bring about certain artistic trends in Nubia originating from rich heritage of Muslim culture. The culture of Christian Nubia originally based to considerable extent on Byzantine art, in course of time, subjected to more and more intense Arabic influence, significantly changed. Arabic components seen in Nubian church architecture, wall painting and art crafts became predominant, which over following centuries led to creation of Arabic culture of the contemporary Sudan.

Keywords: Nubia, early Christianity, Arabs, Byzantium, Christian Church, Nobadia, Makuria

Małgorzata Martens-Czarnecka

Instytut Kultur Śródziemnomorskich i Orientalnych

Polska Akademia Nauk

ul. Nowy Świat 72

00-330 Warszawa, Polska/Poland mmartens@orange.pl 


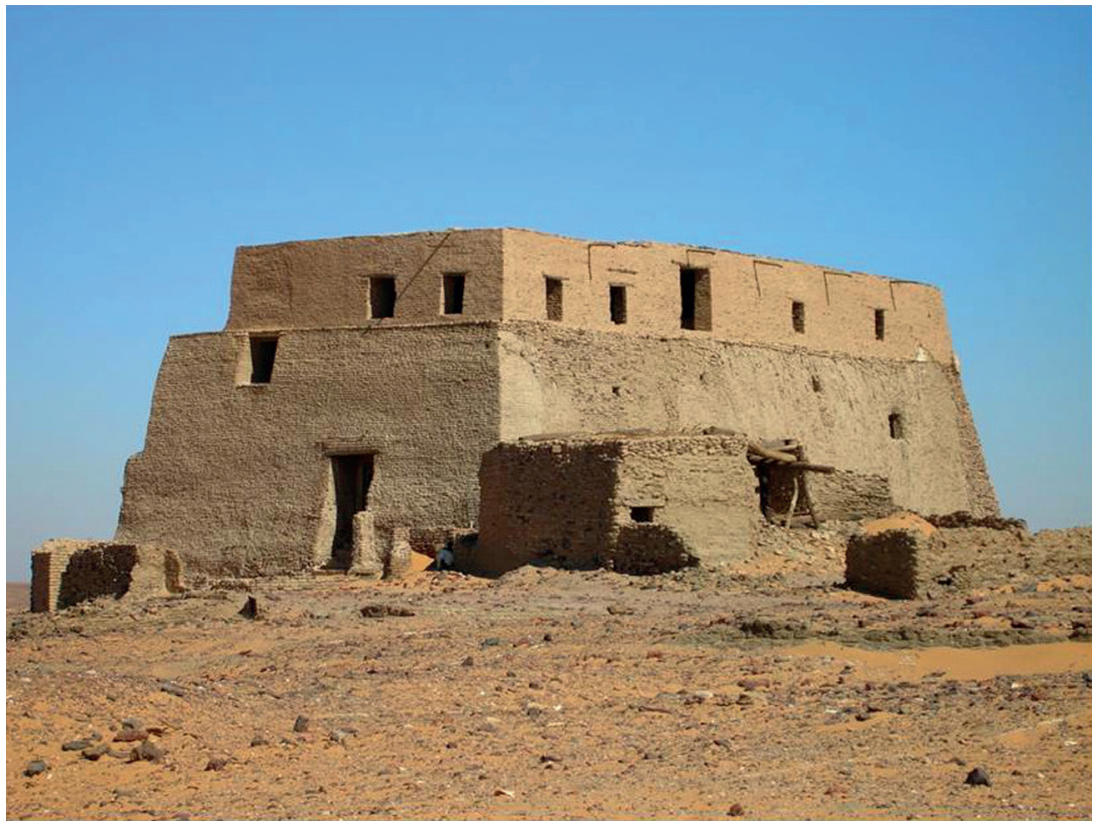

Fig. 2. The royal palace in Dongola converted into a mosque (Photo by the author)

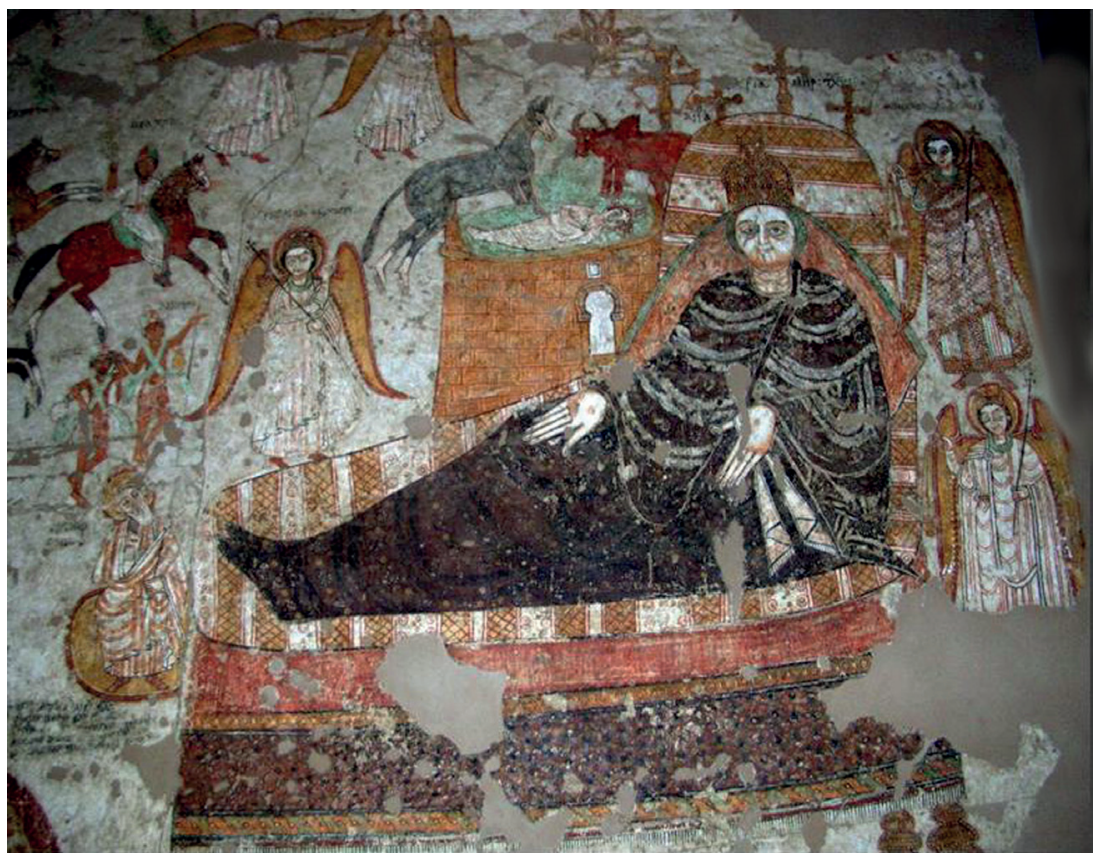

Fig. 3. Nativity from Faras Cathedral - Sudan National Museum in Khartoum (Photo by the author) 


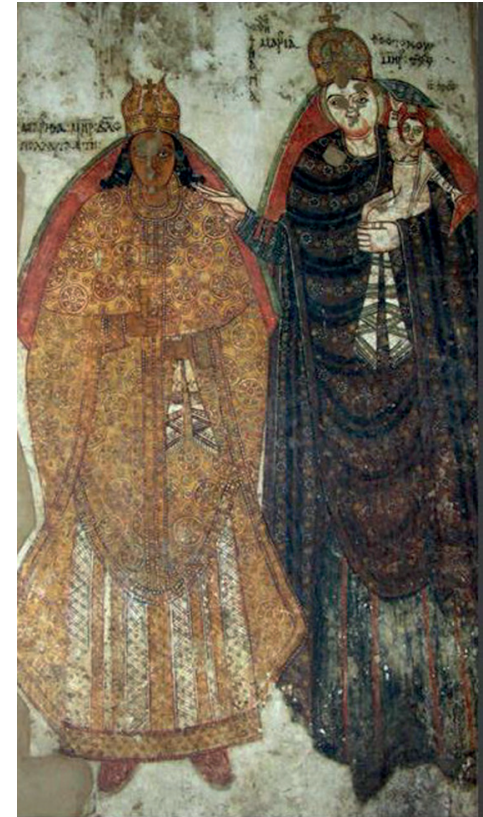

Fig. 4. Martha Mother of the King under protection of St. Mary with the Child - Sudan National Museum in Khartoum (Photo by the author)

Fig. 6. Christ from Northwestern Annex from Old Dongola Monastery (Photo by the author)

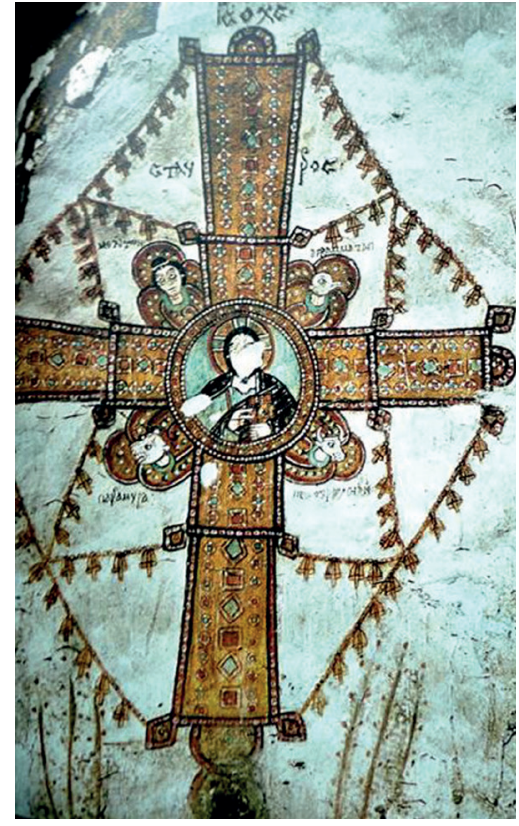

Fig. 5. Votive Cross with Christ at the centre - Sudan National Museum in Khartoum (Photo by the author)

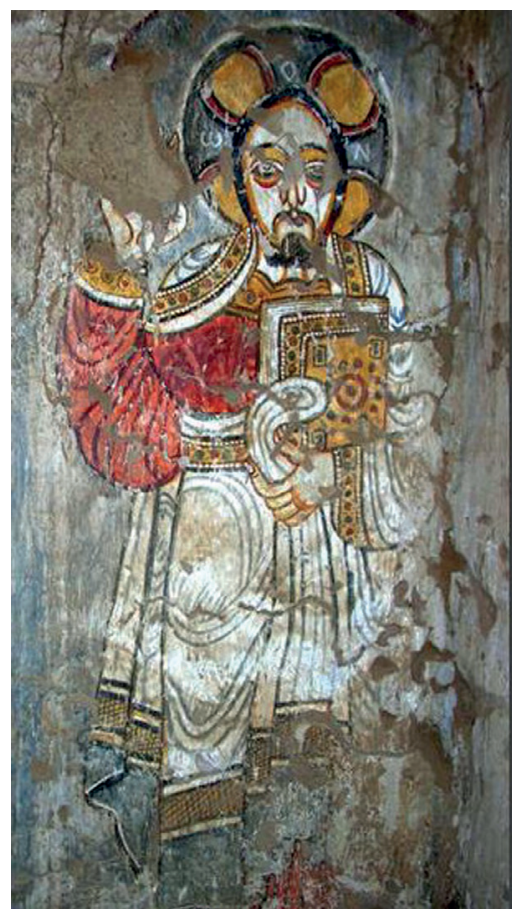




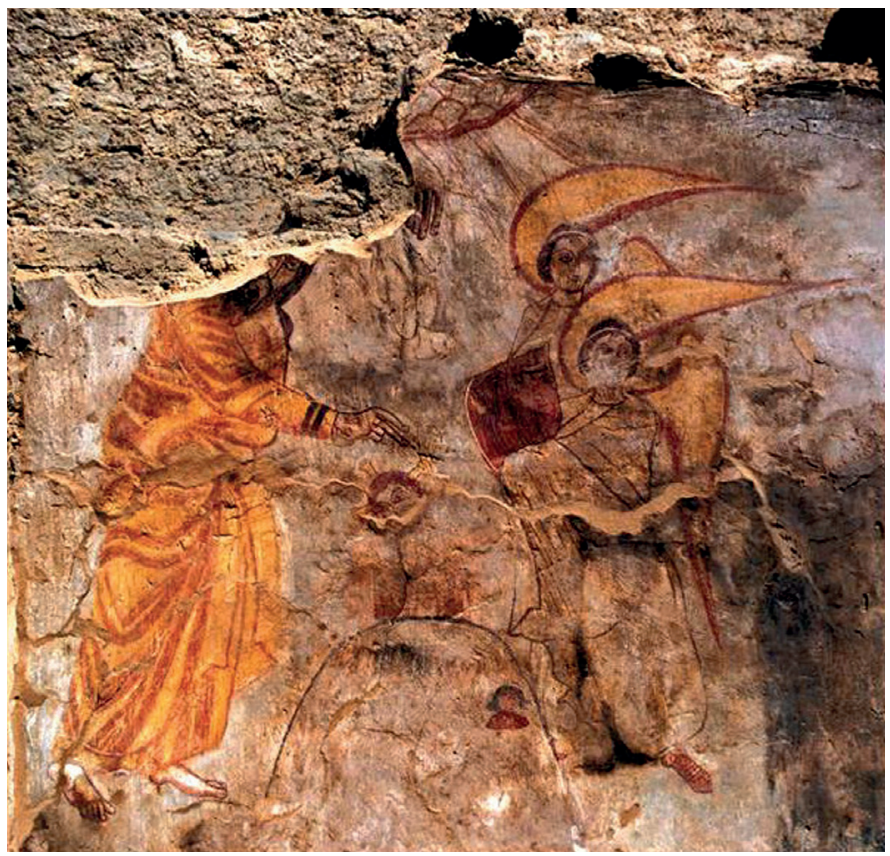

Fig. 7. Baptism of Christ from Northwestern Annex from Old Dongola Monastery (Photo by the author)

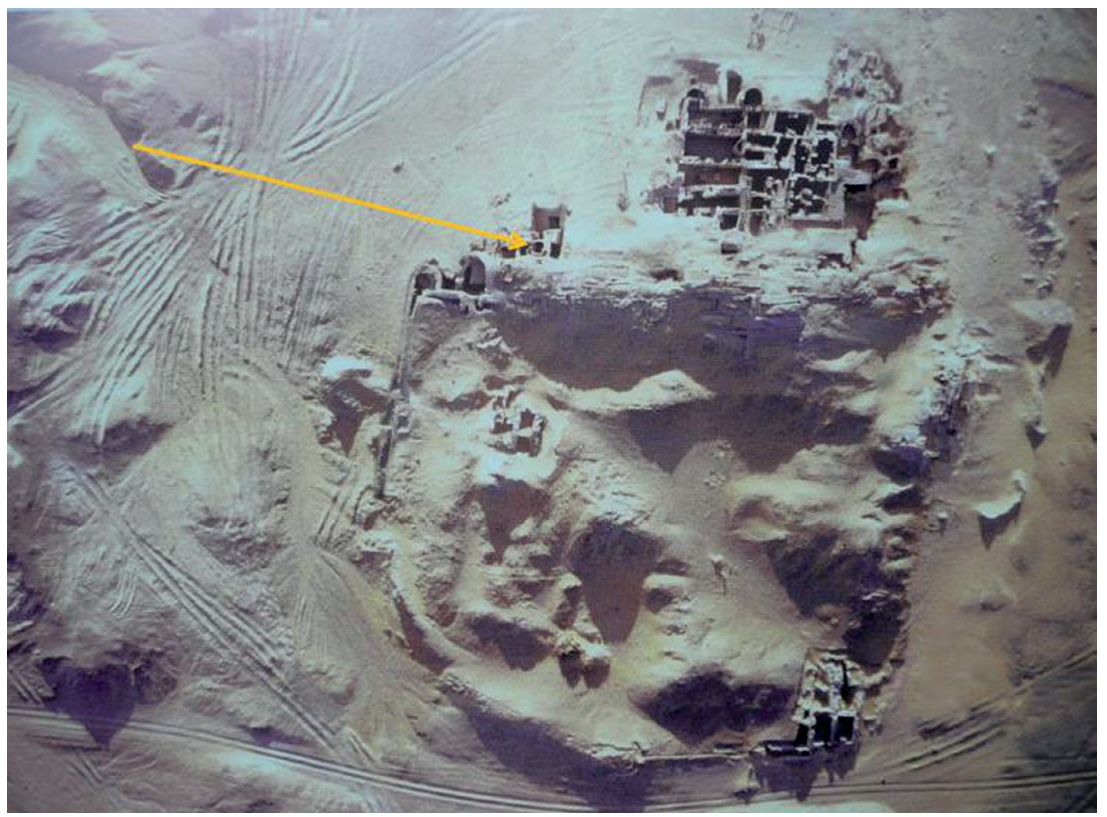

Fig. 8. Monastery compound on kom $\mathrm{H}$ in Old Dongola (Photo by B. Żurawski) 


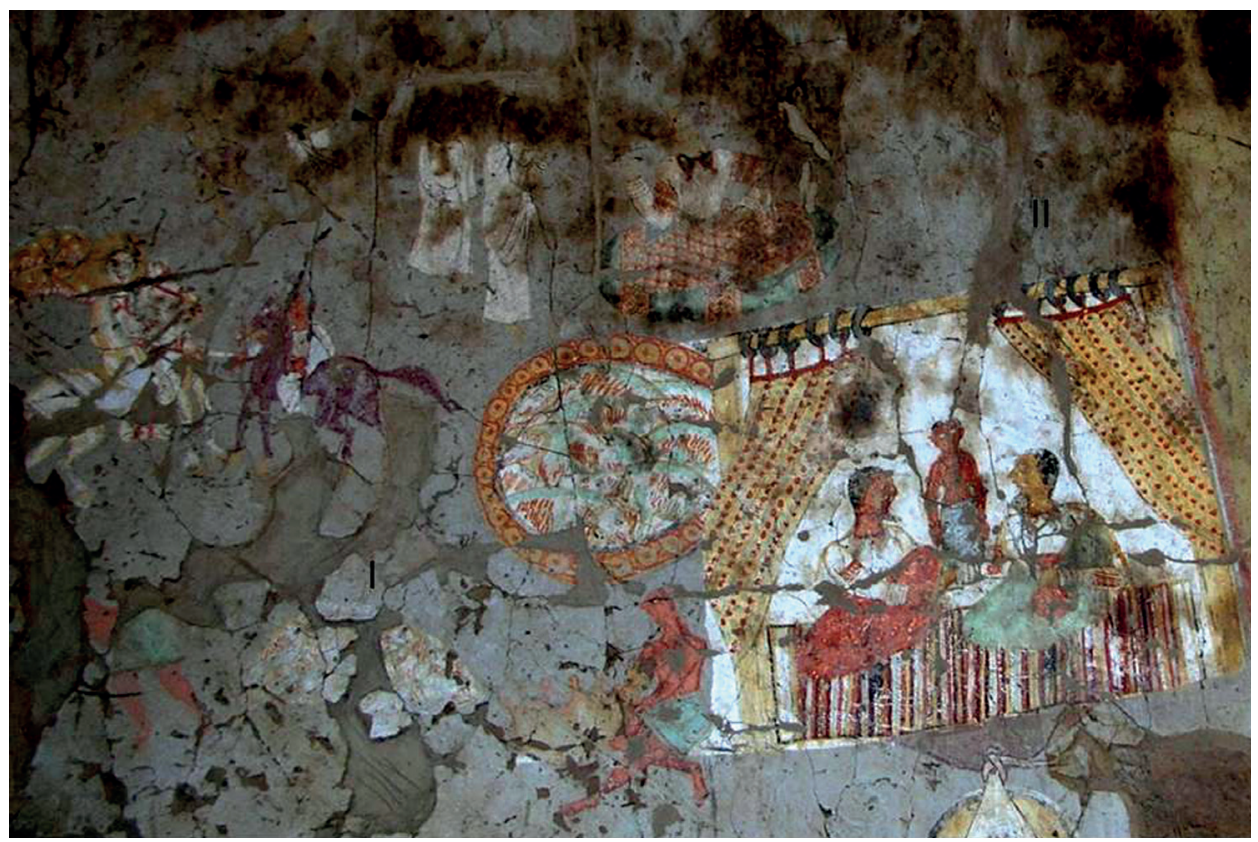

Fig. 9. Story of Tobias - painting from Southwestern Annex from Old Dongola Monastery (Photo. by the author)

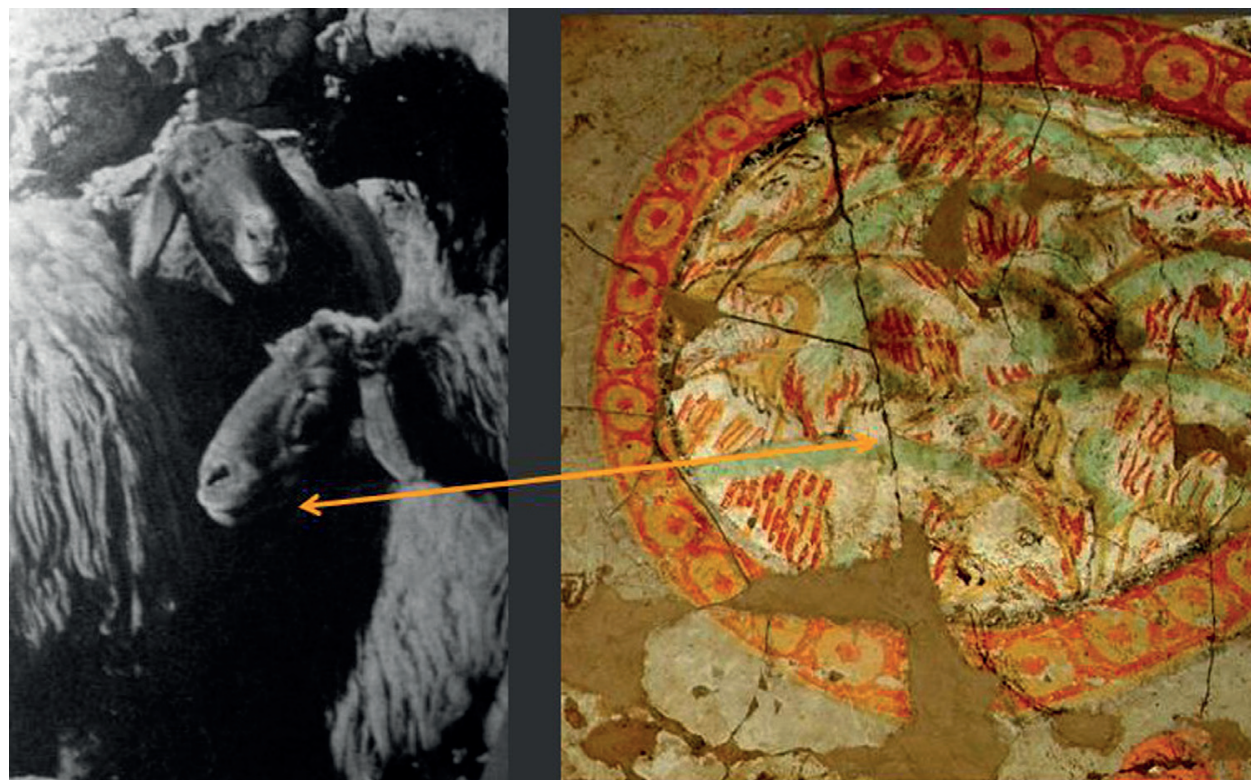

Fig. 10. Sheep corralled in a circular zeriba - fragment of the painting from Southwestern Annex from Old Dongola Monastery (Photo by the author) 


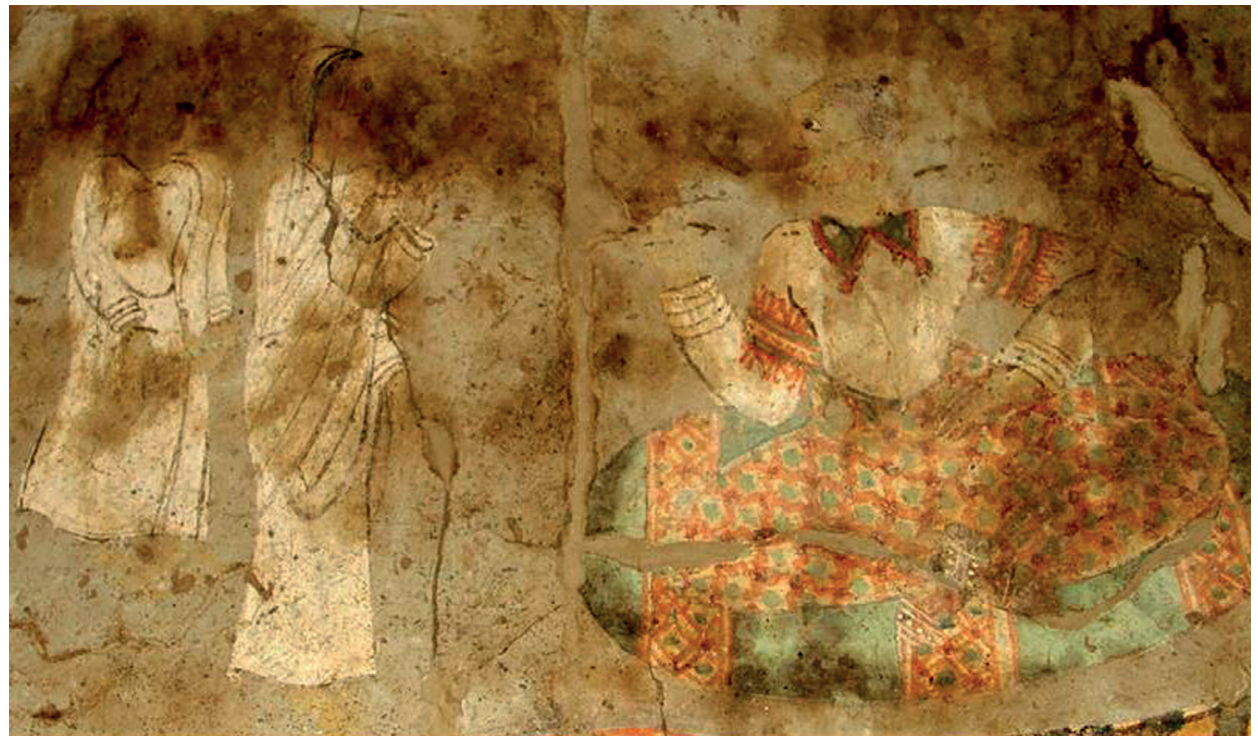

Fig. 11. Tobias and Sara greeted by Raguel - fragment of the painting from Southwestern Annex from Old Dongola Monastery (Photo. by the author)

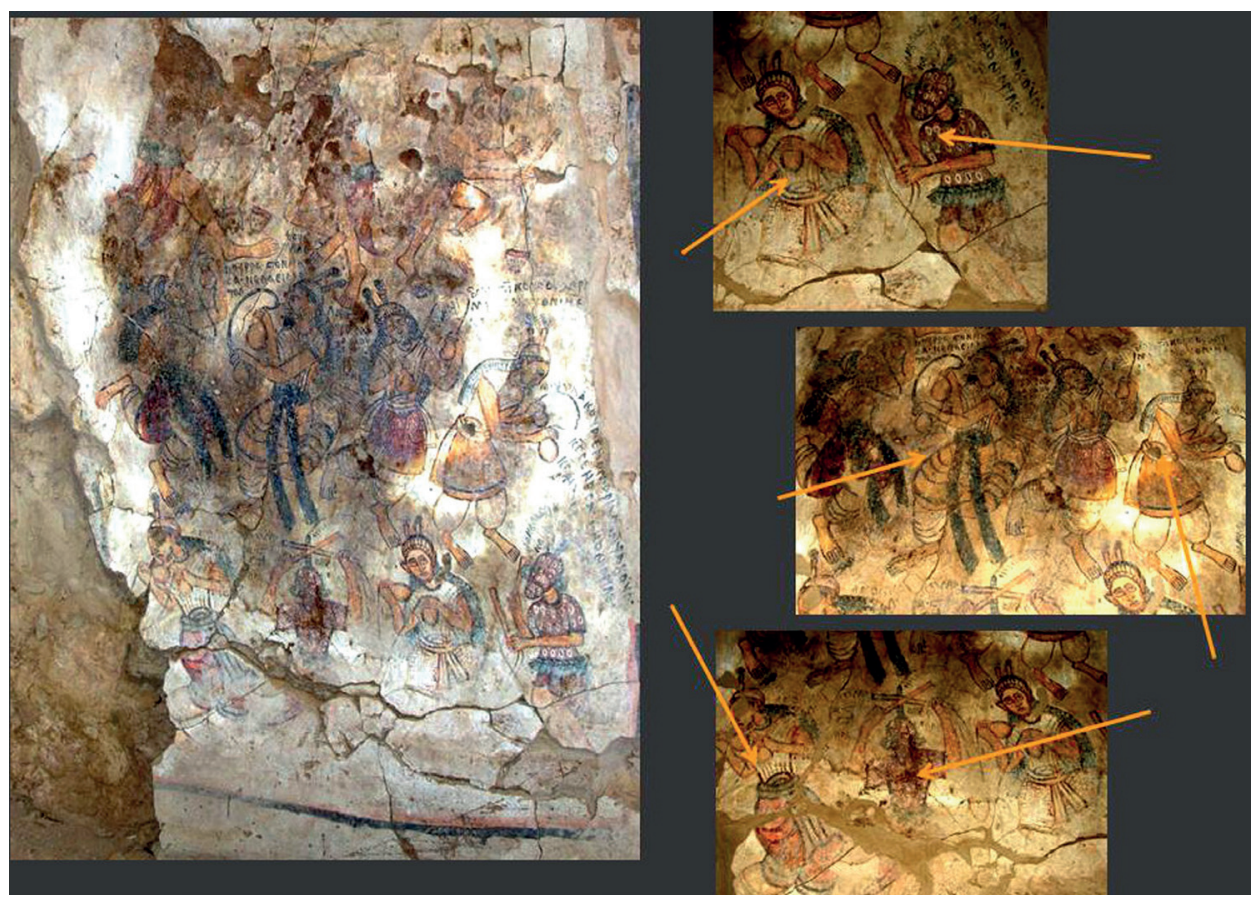

Fig. 12. Dance composition from Southwestern Annex from Old Dongola Monastery (Photo. by the author) 

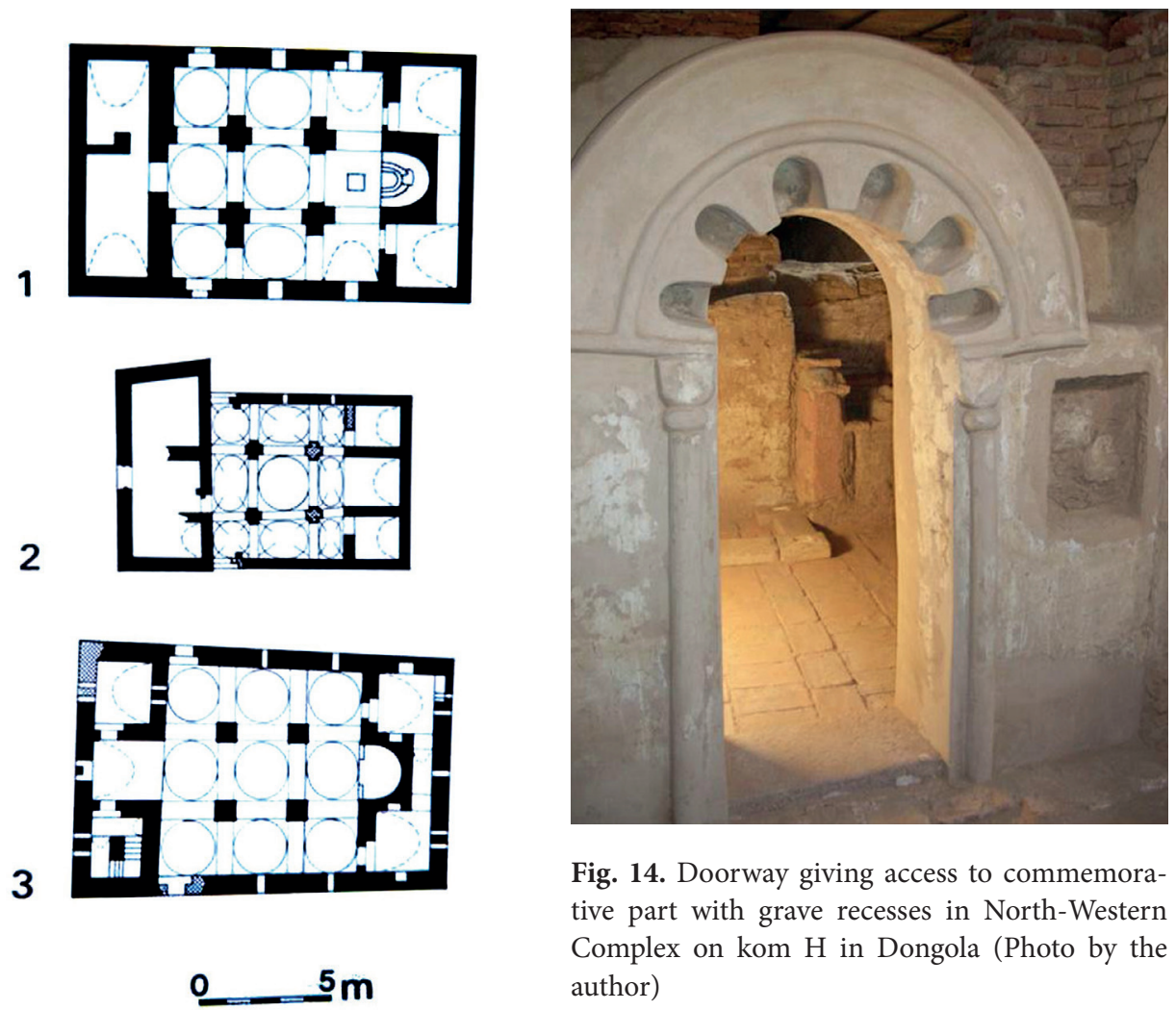

Fig. 14. Doorway giving access to commemorative part with grave recesses in North-Western Complex on kom $\mathrm{H}$ in Dongola (Photo by the author)

Fig. 13. Examples of the plans of the Nubian churches influenced by multi-axial hall composition (after: Gartkiewicz, Babesch 55, 1980, Fig. 19)
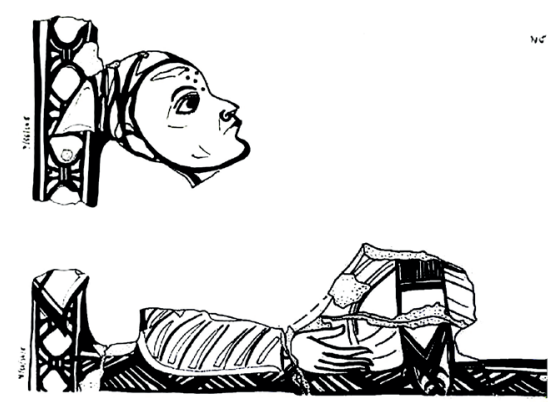

Fig. 15. Ceramic plate that must have decorated interior of the same monastery in Dongola (Design by the author)
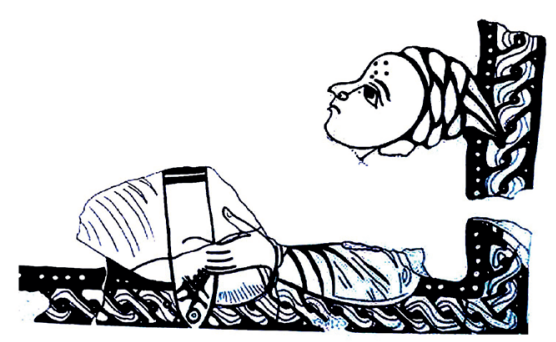

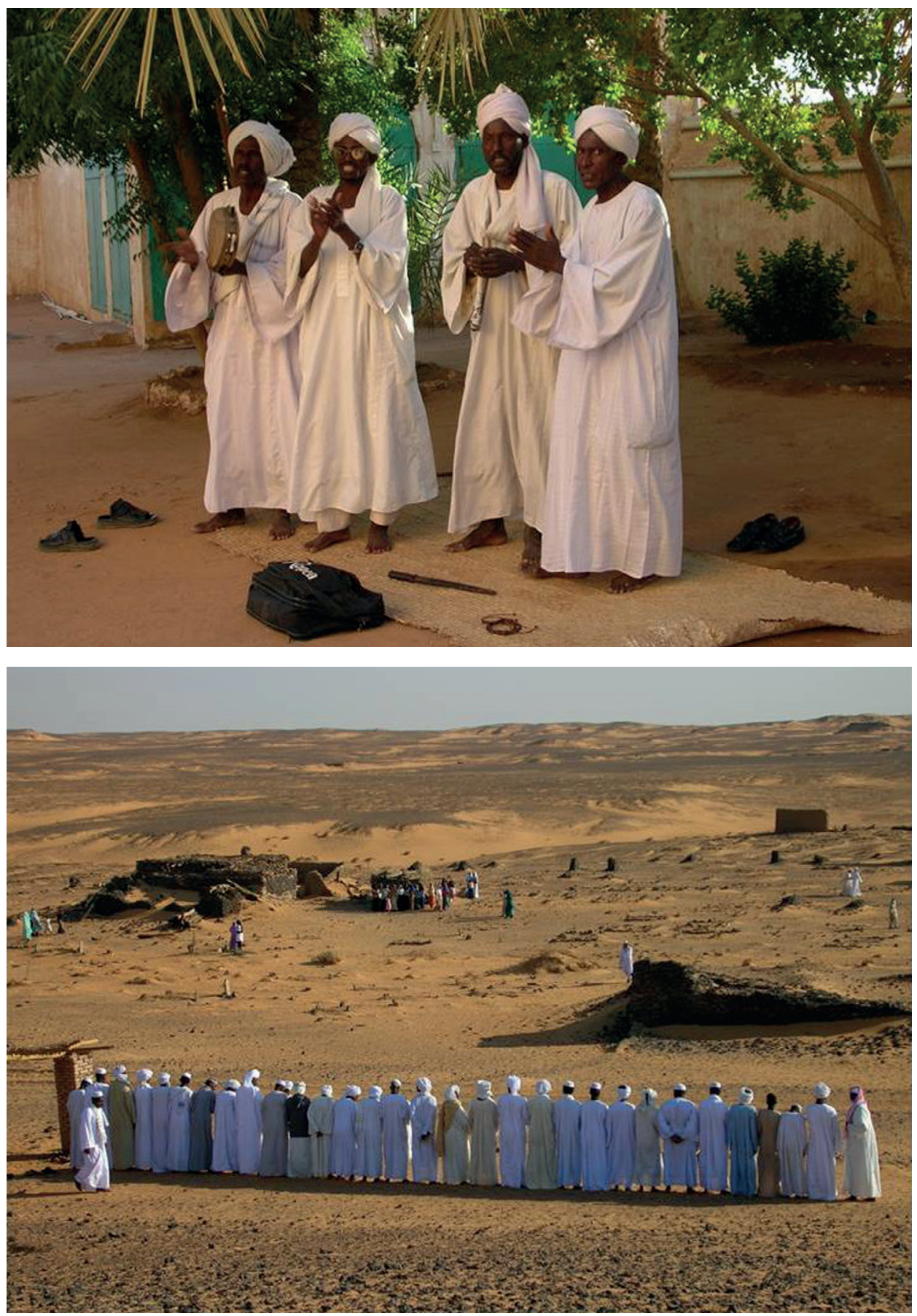

Fig. 16-17. Pictures of the Arabic culture of the contemporary Sudan (Photos by the author) 

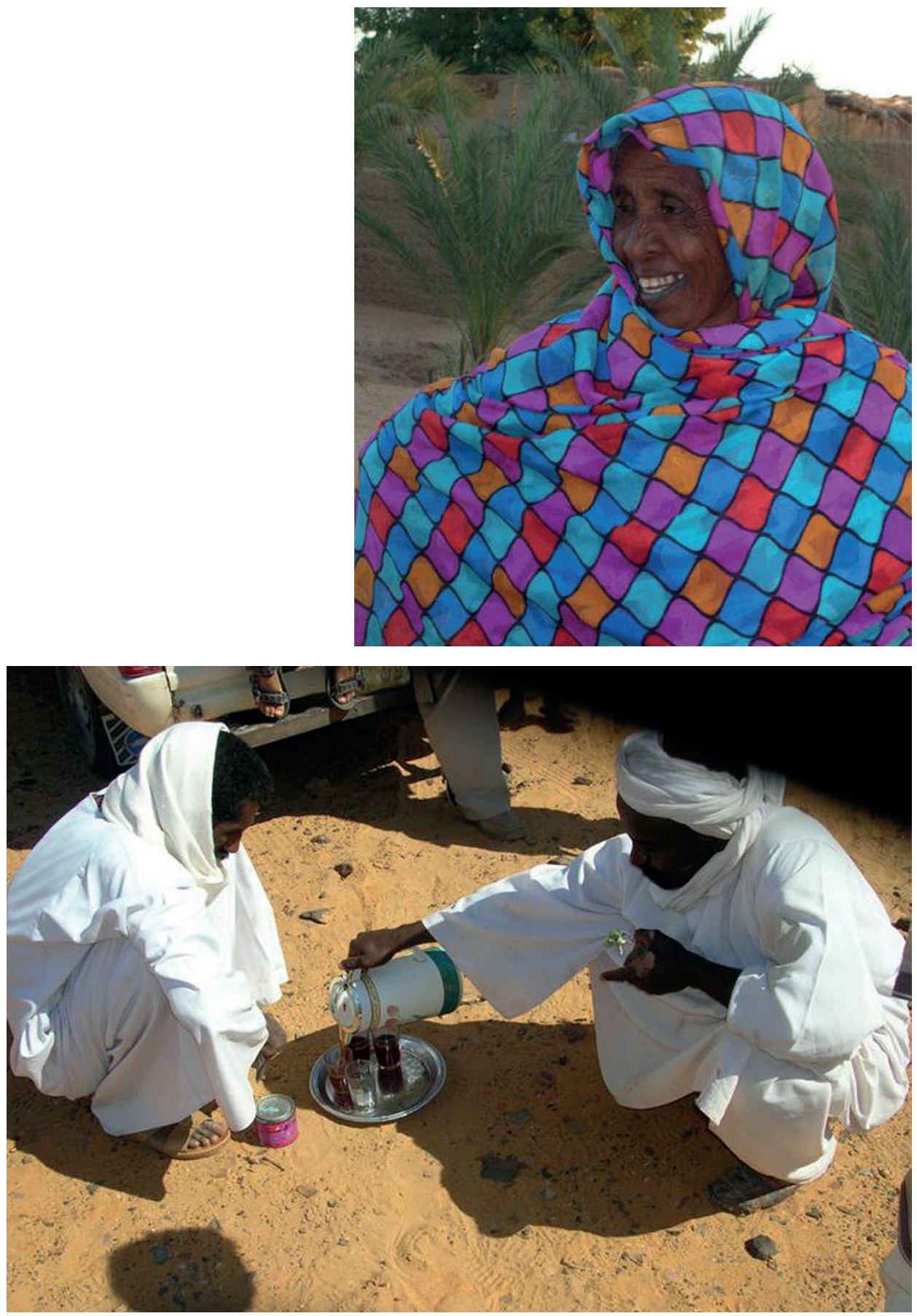

Fig. 16-19. Pictures of the Arabic culture of the contemporary Sudan (Photos by the author) 